Volume 8, No.1.1, 2019

International Journal of Advanced Trends in Computer Science and Engineering

Available Online at http://www.warse.org/IJATCSE/static/pdf/file/ijatcse5681.12019.pdf

https://doi.org/10.30534/ijatcse/2019/5681.12019

\title{
The Selected Relationships in the Area of Transport Management of the Analyzed Company
}

\author{
Marta Kadłubek \\ Faculty of Management \\ Czestochowa University of Technology \\ Częstochowa, Poland \\ martakadlubek@wp.pl
}

\begin{abstract}
The paper reveals the essence of the role of transport management in the activity of the selected company by the identification and analysis of the selected relationships between the selected characteristics. The main subject of the conducted research is to show the significance of management of the area of transport in the analyzed company through the conducted identification and analysis of the amount of supplies of aggregates provided with own fleet in the examined company and the costs of transport of these aggregates. The key part of the research is the indication of the existing relationship between the amount of supplies provided with own fleet and the transport costs in total.
\end{abstract}

Keywords- Transport Management; Road Transport; Enterprise; Linear Relationships

\section{INTRODUCTION}

Transport plays an important role in the activity of each company since its task is to cover a certain distance, and consequently, repeatedly relocate goods from the manufacturer to the customer.

Road transport is the most frequently used from among all the modes of transport, mainly due to rapidity and flexibility which is associated with a dense network of roads. The geographical scope is also important. Road transport is distinguished by a low price as opposed to other modes of transport, lack of necessity to reload, high frequency driving (adjusted to a single customer) and timeliness of provided services.

The objective of the paper is to show the significant role of transport management in the activity of the selected company by means of the identification and analysis of the selected relationships between the selected characteristics.

The main subject matter of the conducted research is to show the significance of management of the area of transport in the examined company by means of the conducted identification and analysis of the amount of supplies of aggregates provided with own fleet in the surveyed company and the costs of transport of these aggregates. The key part of the research is to indicate the existing relationship between the amount of supplies provided with own fleet and the transport costs in total.

\section{THE ESSENCE OF TRANSPORT MANAGEMENT IN THE ACTIVITY OF ENTERPRISES}

Transport is an activity aimed at covering a certain distance, consisting in the provision of services for reward. The result of this activity is displacement of goods or people and, consequently, creating services which are directly related to this. Therefore, properly managed transport [1] allows for an effective operation of enterprises of any industry in the economy [2].

Burnewicz [3], Coyle, Novak, Gibson and Bardi [4], Hajdul, Stajniak, Foltyński, Koliński and Andrzejczyk [5], E. Załoga [6] perceive transport as an activity consisting in the provision of services for reward which is aimed at movement of loads from the point of origin to the point of destination using elements including means and infrastructure of transport, human resources and specific legal regulations. According to Goldsby, Iyengar and Rao [7], Najder [8], Wojewódzka-Król and Rolbiecki [9], transport allows for exchange of goods, while displacing raw materials, intermediate goods, materials and finished products, designed for consumption. In the opinion of Humes [10], Michałowska [11], Brdulak, Banak, Pawlak and Krysiuk [12], transport management enables cooperation and specialization in material production. Therefore, it determines the mass production and the existence and operation of the market of goods and the market economy.

Among various modes of transport, the most popular in business is road transport, one of the most frequently selected by managers of entities, mainly due to its availability, an extensive network of roads or profitability for short distance carriages [13]. Most enterprises operating on the market nowadays use road transport in order to reach customers with their products.

According to Dhugosz [14], road transport is the most frequently used from among all modes of transport since it is characterized by rapidity and flexibility which is caused by a dense network of roads allowing for a delivery of goods to a specific location. The geographical scope, possibility of transporting different types of loads, low prices, compared to other modes of transport, and short transport service provision time are also important. 
Jakubiec [15] indicates the most important features of properly managed road transport including:

- a wide range of means of transport and any devices facilitating transport,

- possible transport for medium and small distances,

- rapidity of transport depending on the condition of infrastructure,

- used in combined transport,

- transport services provided timely and punctually.

According to Neider [16], road transport has gained popularity and has been dynamically developing due to:

- density, consistency and spatial distribution of roads,

- $\quad$ adjustment of road network to the places of trade and production,

- adjustment of means of transport to transport of almost all types ofload,

- lack of need for intermediate transshipment operations,

- timelydeliveries,

- frequency of driving tailored to the customer,

- availability of means of transport in time,

- possibility to choose the most convenient route of shipment.

\section{GENERAL CHARACTERISTICS OF THE ANALYZED COMPANY}

The analyzed company is a global company, established in Mexico in 1906, which deals with production of building materials: The enterprise operates in the area of more than 50 countries, providing high-quality products and services to customers and communities as well as it maintains trade relations with about 108 countries. Nowadays, the company is the leader of the building materials industry, the leading manufacturer of cement in the world and the supplier of readymixed concrete and aggregates, achieving the level of annual sales amounting to USD 15.23 billion in 2015 and employing nearly 44000 employees [17]. The company sets development as its main objective to become more flexible, creative, innovative, effective and sustainable in its activities, which is presented in Figure 1.

The basic activity of the examined company is the extraction and sales of aggregates, production of ready-mixed concrete and cement production. Additionally, the company manufactures construction chemicals, chemical additives for concrete and provides its customers with technical consultancy and transport of products.

When analyzing the financial and business strategy of the company, there should be taken into account a geographically diversified portfolio of assets on profitable markets, which has been directed towards the basic activity of the company, namely the production and sales of cement, ready-mixed concrete and aggregates.

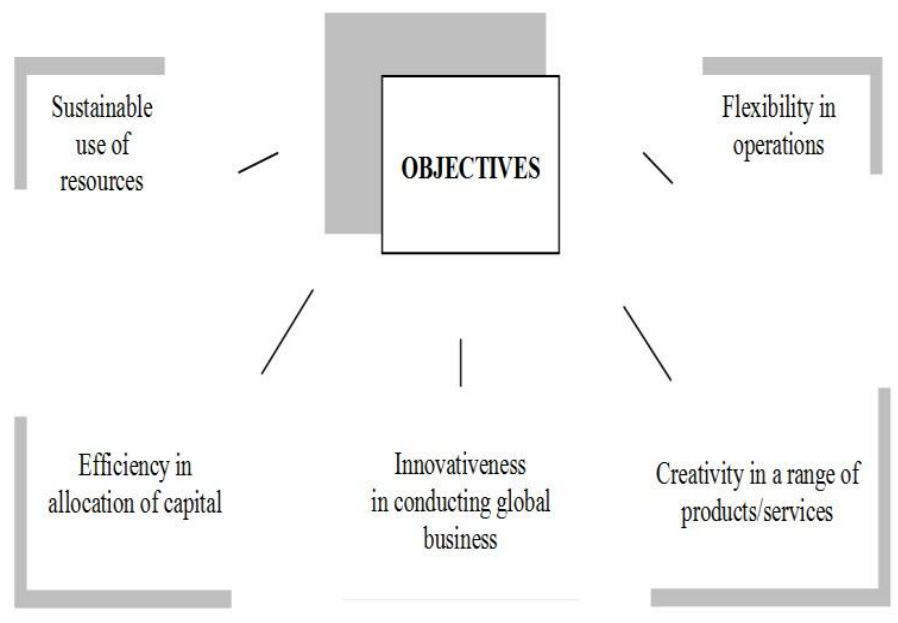

Figure 1: The main objectives of the analyzed company.

The most important values of the analyzed company include [17]:

- safety at work in terms of compliance with the principles of Occupational Health and Safety as well as promotion of safe actions and behavior among employees, communities and contractors,

- concentration on customers, i.e. in particular, close relationships with customers, taking up challenges, understanding and providing solutions,

- perfection, which is expressed in new challenges, constant improvement and increasing expectations,

- unity, which appears in global actions and the global image of the company,

- honesty in relationships with customers, contractors and natural resources.

The company has a branch in Poland, being in the lead of manufacturers of cement, ready-mixed concrete and aggregates. The Polish branch applies international standards concerning production and management, at the same time, creating and providing customers with products of the highest quality. In Poland, there are established three cement plants, 40 concrete plants, 8 mines and the office in Warsaw. These units employ 1137 people in the area of Poland.

The analysis of the activity of the company and the characteristics of the organizational structure indicates the complexity of the company in terms of actions undertaken in the field of management of not only the entire enterprise along with human resources but, most of all, production management. The organizational structure, through a separate approach to the sections responsible for production of readymixed concrete, cement and aggregates indicates how important in the enterprise the quality and safety of production 
is. The structure of the branch in Poland shows that the company globally manages the units in individual countries [18] and globally takes strategic decisions [19] concerning the image of the company in external contacts or the quality of the provided products and services.

\section{THE ANALYSIS OF THE AMOUNT OF SUPPLIES OF AGGREGATES PROVIDED WITH OWN FLEET IN THE ANALYZED COMPANY}

The analyzed company, apart from conducting the basic activity, which is the extraction of aggregates and production of building materials, ought to pay attention to the aspects associated with the sales of its products and, consequently, appropriate organization of transport. The extraction and transport of aggregates constitutes the most significant source of income for the analyzed company due to the fact that aggregates are sold as a raw material and used for the production of cement and ready-mixed concrete. Therefore, in the paper, the attention has been focused on the characteristics and identification of the parameters of the transport of aggregates.

A very important aspect, when organizing transport by the company, is to decide whether own transport or external transport of aggregates is more cost-effective. The enterprise, while conducting the comparative analyses concerning the costs of own transport and external transport, has concluded that the maintenance of own fleet has become unprofitable, therefore, most transport orders are transferred to external carriers. Figure 2 illustrates the amount of supplies provided with own fleet of the company.

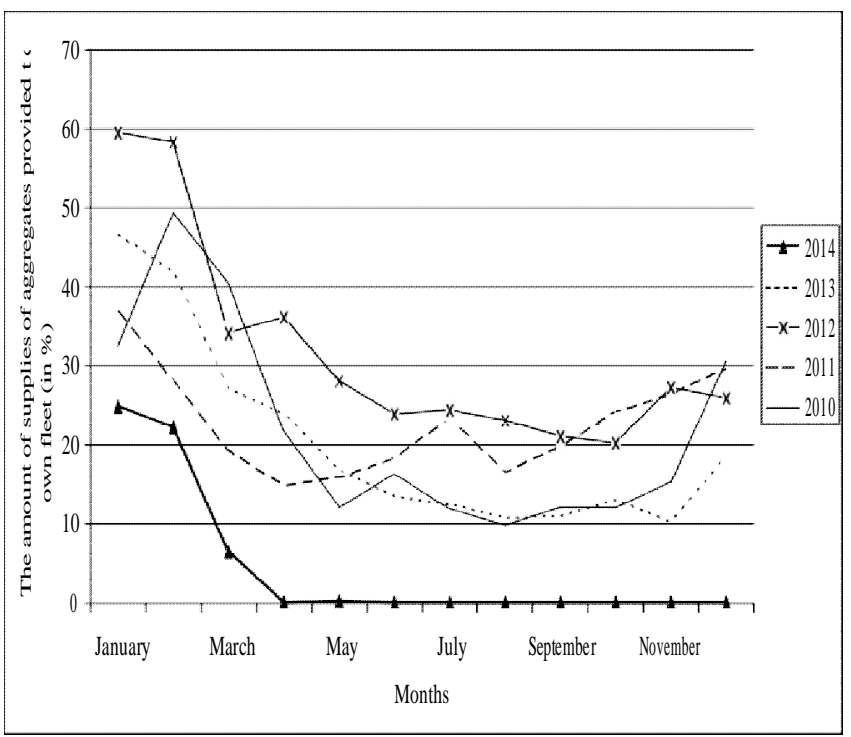

Figure 2: The amount of supplies of aggregates provided to customers with own fleet (in \%).

On the basis of the analysis of the data from the above Figure 2 it is noticeable that the analyzed company has decided on resigning from its own fleet for the benefit of subcontractors. The enterprise has given up deliveries with its own fleet since April 2014, whereas the first three months of 2014 indicated a downward trend. In January 2014 the amount of supplies provided with own fleet amounted to $24.9 \%$, whereas $75.1 \%$ of supplies were dealt with by external fleet. In February $201422.2 \%$ of supplies were handled by own fleet of the company whereas $77.8 \%$ of supplies were dealt with by external fleet. In March 2014 only $6.4 \%$ of supplies were handled by the fleet of the surveyed company, whereas as much as $93.6 \%$ of supplies were dealt with by external fleet. The above Figure 2 also illustrates that, in years 20102013, there was a clear downward trend in the amount of supplies provided with own fleet of the company. There was an increase only in 2013 - by $8.2 \%$ compared to the previous month, which could be due to the necessity to allocate the budget remaining at the end of the year. The sharpest decline occurred in 2013 - from January to October, there was a decrease in the amount of supplies provided with own fleet by $39.3 \%$. Therefore, when analyzing Figure 2, in years 20102014 it can be seen that, at the beginning of each year, the company employed its own fleet due to a small amount of transported aggregates, however, within a year, along with an increase in the amount of transported aggregates there was a marked decline in the amount of supplies provided with own fleet.

\section{THE ANALYSIS OF AGGREGATE TRANSPORT COSTS IN TOTAL}

Apart from the quantitative analysis of supplies of aggregates in the selected company, an important issue is the analysis and, consequently, control of incurred costs [20] associated with the transport of aggregates. Figure 3 presents the costs of road transport of aggregates in total in years 20102014.

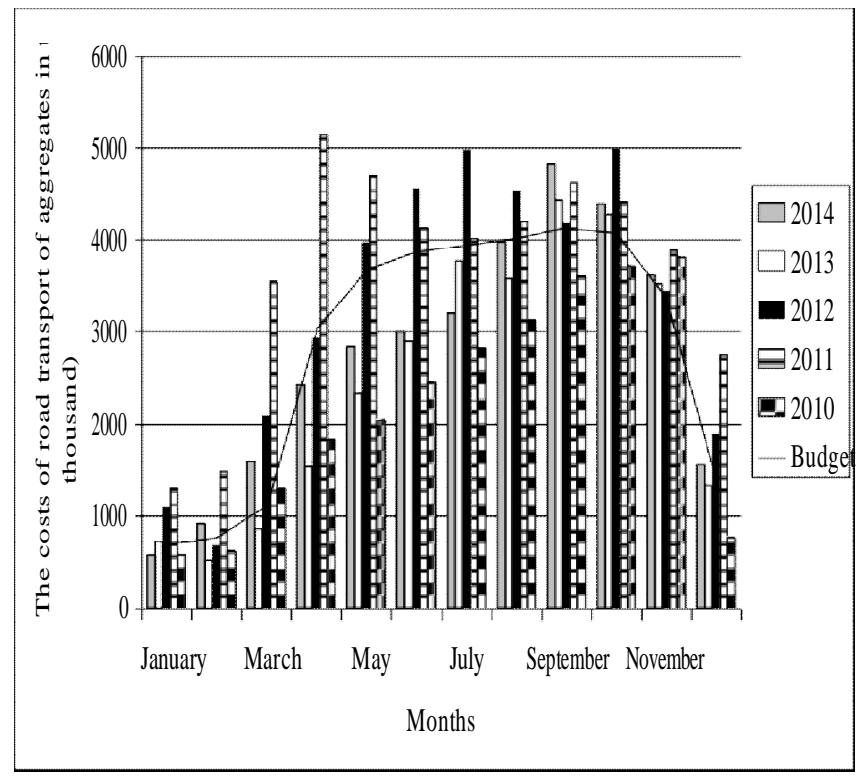

Figure 3: The costs of road transport of aggregates in total (in PLN thousand). 
On the basis of the analysis of the data presented in Figure 3 it can be concluded that in 2014, compared to 2013, the costs of road transport of aggregates were significantly lower. The largest increase, as much as by $85 \%$, occurred in March (from PLN 867000 to PLN 160000), then in February by $73 \%$ (from PLN 537000 to PLN 929000) and in April - by 56\% (from PLN 1556000 to PLN 2427000). A decrease in incurred costs in 2014, compared to 2013, occurred only in two months - in January - a decline by 22\% (from PLN 740000 to PLN 577000 ) and in July - a decline by $15 \%$ (from PLN 3766000 to PLN 3203000). The highest transport costs in 2014 were recorded in September (PLN 4834000), October (PLN 4391000) and August (PLN 3974000). Such high transport costs in August, September and October are associated with a large amount of aggregates transported at that time. Figure 3 also illustrates the differences between the costs of transported aggregates in years 2010-2014. Therefore, there can be noticed a sharp decline in the amount of costs in years 20132014 compared to the years of 2011-2012. Differences in transport costs are not due to the amount of aggregates since in April 2011, when there occurred the highest transport costs, the amount of transported aggregates was not the largest, therefore there is no correlation in this aspect. Such significant differences may be due to the lack of activities in the company aimed at reduction and optimization of logistics costs. Only in 2012 the company invested in the development of the logistics department and the results are noticeable in the analyses presented above. The data illustrated in Figure 3 also allow to indicate the seasonality in incurred costs, which is shown in Figure 4.

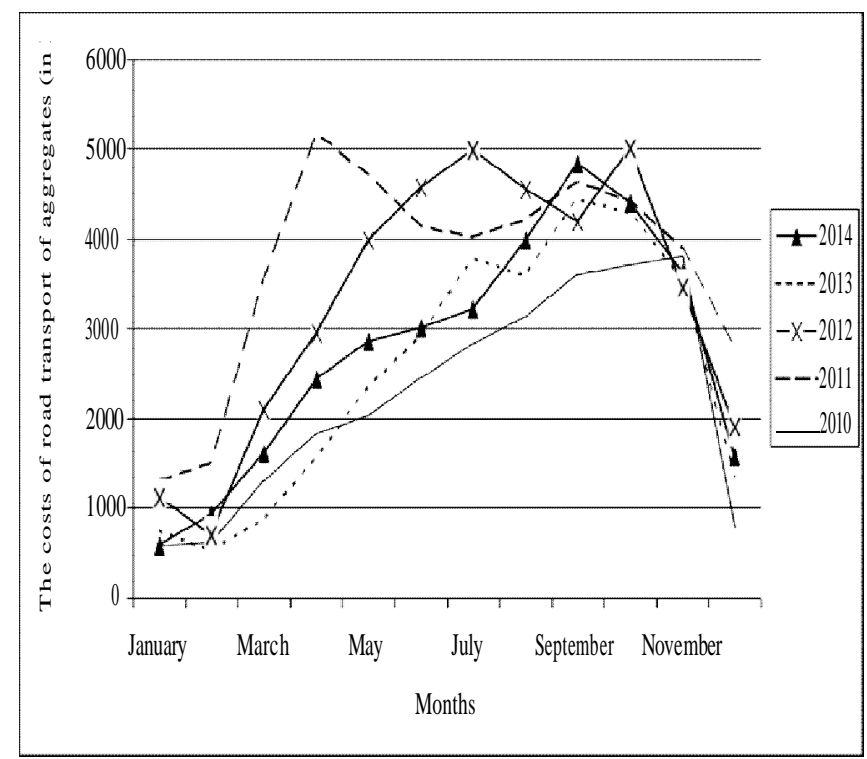

Figure 4: The seasonality of aggregate transport costs in total in years 2010- 2014.

The above Figure 4 shows the seasonality of the analyzed feature which is aggregate transport costs in total in years 2010-2014. The figure clearly indicates that from January to September/October the costs increased in order to subsequently fall to the level similar to the one occurring at the beginning of the year. Only in 2011, transport costs suddenly increased in April in order to decrease slowly until December.

\section{THE RELATIONSHIP BETWEEN THE AMOUNT OF SUPPLIES PROVIDED WITH OWN FLEET AND THE COSTS OF TRANSPORT IN TOTAL IN THE ANALYZED COMPANY}

The figures and analyses presented in the previous subchapters of the paper allowed for conducting the statistical research [21], which consists in the presentation of linear relationships between the series of two different data and they show if the data are interdependent and to what extent. In the analyzed case, to conduct the research into the relationship of the series of data, the following formulas should be used:

1. Arithmetic mean - indicates the average value of the series of data [22]:

$$
x^{-}=\frac{\sum_{i=1}^{n} x_{i}}{n}
$$

where:

$x^{-}$- arithmetic mean,

$n$ - number of examined variables,

$x_{i}$ - characteristic type of the examined variable.

2. Pearson's correlation coefficient - indicates the level of the relationship between the variables $\mathrm{x}$ and $\mathrm{y}$ [23]:

$$
\mathrm{R}_{\mathrm{xy}}=\frac{\Sigma\left(x_{i}-\bar{x}\right) *\left(y_{i}-\bar{y}\right)}{\sqrt{\sum\left(x_{i}-\bar{x}\right)^{2} *\left(y_{i}-\bar{y}\right)^{2}}},
$$

where:

$$
\begin{aligned}
& \mathrm{R}_{\mathrm{xy}} \text { - Pearson's correlation coefficient, } \\
& x^{-} \text {- arithmetic mean of the } \mathrm{x} \text { data series, } \\
& y^{-} \text {- arithmetic mean of the y data series, } \\
& x_{i} \text { - the examined variable } \mathrm{x}, \\
& y_{i} \text { - the examined variable } \mathrm{y} .
\end{aligned}
$$

Table 1 below indicates the calculations necessary to examine Pearson's correlation coefficient between the amount of supplies provided with own fleet and the total transport costs.

On the basis of the above data, there has been developed Figure 5, which presents the linear relationship between the examined variables. 
Table 1: Breakdown of the amount of supplies provided with own fleet and the costs of transport in total in 2013 and supporing calculations for the calculation of pearson's correlation coefficient

\begin{tabular}{|c|c|c|c|c|c|c|c|c|}
\hline$\overline{\text { Date }}$ & $\mathbb{X i}$ & Yi & $\overline{\mathrm{Xi}-x^{2}}$ & Yi-y & $(X i-x)(Y-y)$ & $(\overline{\lambda i-x})^{\wedge} 2$ & 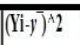 & 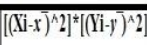 \\
\hline 01.2013 & 0.465 & 740 & 0.261 & .1752 .33 & -457.359 & 0.068121 & 3070672.11 & 209177.2549 \\
\hline 02.2013 & 0.418 & 537 & 0.214 & .1955 .33 & -418.441333 & 0.045796 & 3823328.4 & 175093.1494 \\
\hline 03.2013 & 0.27 & 867 & 0.066 & -1625.33 & .107 .272 & 0.004356 & 2641708.44 & 11507.28198 \\
\hline 04.2013 & 0.239 & 1556 & 0.035 & $\begin{array}{l}-936.333 \\
\end{array}$ & -32.7716667 & 0.001225 & 876720.111 & 1073.982136 \\
\hline $\mid 05.2013$ & 0.166 & 2335 & -0.038 & .157 .333 & 597866667 & 0.001444 & 24753.7778 & 35.7445511 \\
\hline 06.2013 & 0.134 & 2913 & -0.07 & 420.6667 & -29.4466667 & 0.0049 & 176960.444 & 867.1061778 \\
\hline 07.2013 & 0.124 & 3766 & -0.08 & 1273.667 & -101.893333 & 0.0064 & 1622226.78 & 10382.25138 \\
\hline 08.2013 & 0.107 & 3594 & -0.097 & \begin{tabular}{|l|l|}
1101.667 \\
\end{tabular} & 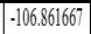 & 0.009409 & 1213669.44 & 11419.4158 \\
\hline 09.2013 & 0.109 & 4439 & -0.095 & \begin{tabular}{|l|l|}
1946.667 \\
\end{tabular} & -184.9333333 & 0.009025 & 3789511.11 & 34200.33778 \\
\hline 10.2013 & 0.13 & 4290 & -0.074 & \begin{tabular}{|l|l}
1797.667 \\
\end{tabular} & -133.027333 & 0.005476 & 3231605.44 & 17696.27141 \\
\hline 11.2013 & 0.102 & 3527 & -0.102 & \begin{tabular}{|l|l|}
1034.667 \\
\end{tabular} & 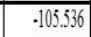 & 0.010404 & 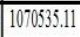 & 11137.8473 \\
\hline 12.2013 & 0.184 & 1344 & -0.02 & 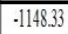 & 22.9666667 & 0.0004 & 1318669.44 & 527.4677778 \\
\hline Anithmetic & 0.204 & 2492.33333 & & & & & & \\
\hline Total & & & & & .1648 .597 & 0.166956 & 22860360.7 & \\
\hline$\widehat{R_{\text {II }}}$ & -0.843863 & & & & & & & \\
\hline
\end{tabular}

Legend:

$\mathrm{X}_{\mathrm{i}^{-}}$amount of supplies provided with own fleet (\%),

$\mathrm{Y}_{\mathrm{i}^{-}}$costs of transport in total (PLN thousand).

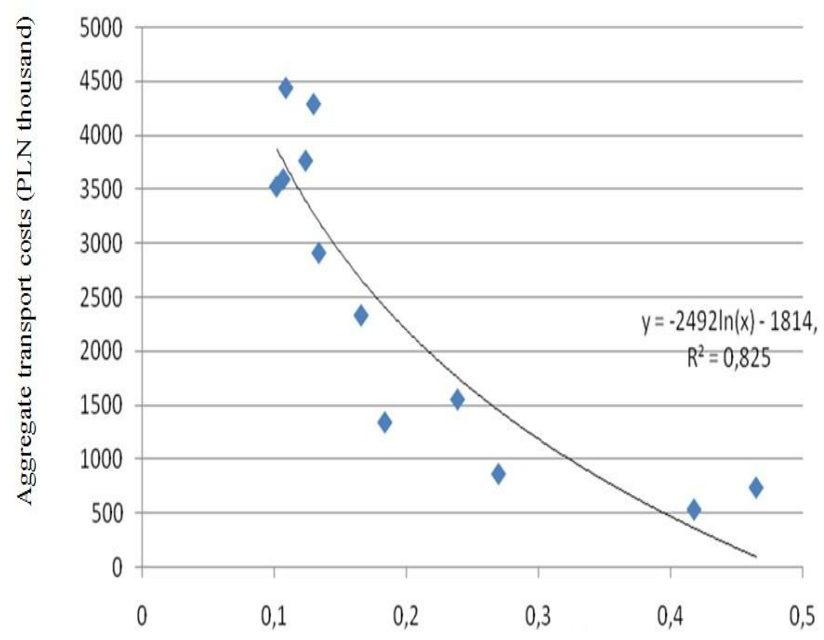

The amount of supplies provided with own fleet (\%)

Figure 5: The relationship between the amount of supplies provided with own fleet and aggregate transport costs in 2013.

Pearson's correlation coefficient amounts to -0.843 in this case. The analysis of the presented data indicates that aggregate transport costs (PLN thousand) are highly dependent on (the result ranging from 0.8 to 0.9 ) the amount of supplies provided with own fleet $(\%)$. The figure clearly indicates a very high negative linear relationship. This means that transport costs fall when there is an increase in the amount of supplies provided with own fleet. Not only in 2013 was there a high negative linear relationship. Tables 2 and 3 below present the breakdown of the amount of supplies provided with own fleet and transport costs in years 2010-2014.

Table 2: Breakdown of the amount of supplies provided with own fleet and transport costs in years 2010-2014

\begin{tabular}{|c|c|c|c|c|c|c|c|c|c|c|c|c|c|c|}
\hline ind 1 & 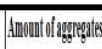 & ?III & 025 & 022 & 0.6 & 0.00 & 0.00 & 000 & 0.00 & 0.00 & 0.00 & 0.00 & 0.00 & 0.0 \\
\hline Int? & & 2013 & 0.47 & 0.4 & 0.7 & 0.24 & 0.17 & 0.13 & 0.12 & 0.11 & 0.11 & 0.13 & 0.10 & 0.1 \\
\hline [int?] & & 2011 & 0.00 & 0.88 & D.34 & 0.36 & 0.28 & 024 & 024 & 023 & 0.21 & 012 & 0.7 & 02 \\
\hline nt. & & \begin{tabular}{|l|l|} 
\\
\end{tabular} & $0.37^{\circ}$ & 028 & 0.19 & 0.15 & 0.16 & 0.18 & 023 & 0.16 & 0.20 & 024 & 0.66 & 7. \\
\hline |Lint. & & 28110 & 0.33 & 0.49 & 0.40 & 021 & 0.12 & 0.16 & 0.12 & 0.10 & 0.12 & 0.12 & 0.15 & 031 \\
\hline $\operatorname{Lin} 6$ & Traspoutusts & 2314 & $5 \pi$ & 98 & 16613 & 242 & $287^{7}$ & 3004 & 3013 & 397 & 483. & 4399 & 3620 & 15 \\
\hline inf? & & 21113 & 70 & 53 & 867 & 1566 & 2335 & 2913 & 3766 & 3994 & 439 & 420 & 362 & 134 \\
\hline Lined & & 2011 & 1110 & 70. & 2998 & 2950 & 397 & 475 & 1976 & 4,438 & 4186 & 502 & $3+48$ & 191.5 \\
\hline inet & & 23011 & 1338 & 1498 & 3538 & 51155 & 4608 & $4 \mid 14$ & 4028 & $4[13$ & 4619 & 419 & 388 & 77 \\
\hline$|t|$ & & 2111 & 5758 & 6232 & 1304 & 1889 & 2030 & 248 & 1834 & 31125 & 3397 & 3726 & 3319 & 781 \\
\hline
\end{tabular}

The above Table 2 presenting the breakdown of the amount of supplies provided with own fleet and transport costs in years 2010-2014 has allowed to indicate the relationships between two variables in individual years, which is presented in Table 3.

TABLE 3: The Relationships Between The Amount Of Supplies Provided With Own Fleet And Transport Costs In Years 2010-2014

\begin{tabular}{|l|c|c|c|c|c|}
\hline & \multicolumn{1}{|c|}{ Line 1 } & \multicolumn{1}{c|}{ Line 2 } & \multicolumn{1}{c|}{ Line 3 } & \multicolumn{1}{c|}{ Line 4 } & \multicolumn{1}{c|}{ Line 5 } \\
\hline Line 6 & -0.74452 & -0.86873 & -0.8261 & -0.531 & -0.85680 \\
\hline Line 7 & -0.6745 & -0.84386 & -0.79194 & -0.35403 & -0.87745 \\
\hline Line 8 & -0.78630 & -0.87132 & -0.85114 & -0.58874 & -0.91959 \\
\hline Line 9 & -0.88276 & -0.80565 & -0.80191 & -0.8537 & -0.77150 \\
\hline Line 10 & -0.67638 & -0.82826 & -0.7525 & -0.41917 & -0.83177 \\
\hline
\end{tabular}

The above analyses indicate the linear relationships between the amount of supplies provided with own fleet and transport costs in years 2010-2014. In years 2010-2014 the value of the correlation was in the range of $0.6-0.8$ and 0.8 0.9 . This means that there is a high or very high negative relationship between the examined variables.

The above correlation indicates that in years 2010-2014 along with an increase in the amount of supplies provided with own fleet there was a decline in transport costs. It is worth pinpointing that since April 2014, the analyzed company has given up own fleet for the benefit of transport provided by external carriers. The managers responsible for this area of 
transport in the company ought to consider deeply why, in the case of the positive impact of supplies provided with own fleet, the company resigns from this type of transport and chooses transport provided with external fleet running the risk of higher and unnecessary costs.

\section{CONCLUSION}

Transport plays the key role in the analyzed company. Without transport, the operation of the enterprise, both in terms of the production of goods and distribution of goods to customers would not be possible.

The analyses of the amount of supplies provided with own fleet indicated that in January 2014 the amount of supplies provided with own fleet amounted to $24.9 \%$, whereas $75.1 \%$ of supplies were handled by external fleet, In February 2014 $22.2 \%$ of supplies were provided with own fleet of the company whereas $77.8 \%$ of supplies were provided with external fleet. In March 2014 only 6.4\% of supplies were handled by own fleet of the analyzed company whereas as much as $93.6 \%$ of supplies were dealt with by external fleet. A major decline occurred in 2013 - from January to October, there was a decrease in supplies provided with own fleet by $39.3 \%$.

The analysis of aggregate transport costs indicated that in 2014, compared to 2013, the costs of road transport of aggregates in total were significantly higher. The sharpest increase in costs, as much as by $85 \%$, was in March and then in February by $73 \%$ and in April - by $56 \%$. A decline in incurred costs in 2014, compared to the year of 2013, occurred only in two months - in January - a decline by $22 \%$ and in July - a decrease by $15 \%$. The highest transport costs in 2014 were recorded in September, October and August.

The analysis of the relationships between the amount of supplies provided with own fleet and aggregate transport costs in 2013 indicated that in years 2010-2014 the value of the correlation was in the range of $0.6-0.8$ and $0.8-0.9$, which amounts to a high or very high negative relationship between the examined variables. The above correlation indicates that in years 2010-2014 along with an increase in the amount of supplies provided with own fleet, there was a decrease in transport costs.

Summing up, it should be pinpointed that a wellconsidered and, consequently, well-managed system of transport of goods in the company is the key to succeed in terms of competitiveness. Due to the transport system, the enterprise is able to satisfy all the needs of customers associated with timeliness of deliveries. Transport, as an element combining many areas of the activity of the company, helps to achieve the competitive position on the market and constitutes the key area of cost optimization.

\section{REFERENCES}

[1] S. Lachiewicz and B. Nogalski, Osiągnięcia i perspektywy nauk o zarządzaniu, Warszawa: Wolters Kluwer Polska, 2010.

[2] K. Wojewódzka- Król and W. Rydzkowski, Transport, Warszawa: PWN, 2009.

[3] J. Burnewicz, „Czynniki rozwojowe polskiego transportu drogowego," Zeszyty Naukowe Uniwersytetu Gdańskiego Ekonomika Transportu i Logistyka, vol. 54, pp. 35-86, 2015.
[4] J.J. Coyle, R.A. Novak, B. Gibson, and E.J. Bardi, Transportation: A Supply Chain Perspective, Canada: South-Western College Pub., 2010.

[5] M. Hajdul, M. Stajniak, M. Foltyński, A. Koliński, and P. Andrzejczyk, Organizacja i monitorowanie procesów transportowych, Poznań: Wyd. Instytut Logistyki i Magazynowania, 2015.

[6] E. Załoga, Trendy w transporcie lądowym Unii Europejskiej, Szczecin: Wydawnictwo Uniwersytetu Szczecińskiego, 2013.

[7] T.J. Goldsby, D. Iyengar, and S. Rao, The defivitive guide to transportation: principles, strategies, and decisions for the effective flow of goods and services, USA: Council of Dupply Chain Management Professionals, 2014.

[8] J. Neider, Transport w handlu międzynarodowym, Gdańsk: Wyd. Uniwersytetu Gdańskiego, 2006.

[9] K. Wojewódzka-Król and R. Rolbiecki, Polityka rozwoju transportu, Gdańsk: Wydawnictwo Uniwersytetu Gdańskiego, 2013.

[10]E. Humes, Door to door: the magnificent, maddening, mysterious word of transportation, New York: Harper Pub., 2016.

[11]M. Michałowska, Efektywny transport, Katowice: Wyd. Akademii Ekonomicznej, 2009.

[12] J. Brdulak, M. Banak, P. Pawlak, and C. Krysiuk, Kierunki rozwoju infrastruktury transportu samochodowego w Polsce, Warszawa: Wydawnictwo ITS, 2014.

[13]D. Rucińska, Rynek usług transportowych w Polsce: teoria i praktyka, Warszawa: PWE, 2015.

[14]J. Długosz, Nowoczesne technologie w logistyce, Warszawa: Polskie Wydawnictwo Ekonomiczne, 2009.

[15]M. Jakubiec, „Transport drogowy jako element logistyki miejskiej," Logistyka, vol. 3, pp. 2477-2492, 2014.

[16]J. Neider, Transport międzynarodowy, Warszawa: Polskie Wydawnictwo Ekonomiczne, 2008.

[17] Internal materials of analyzed Company, Rudniki 2016.

[18] J. Nowakowska-Grunt and M. Strzelczyk, „Influence of Road Transport on the Environment - Poland Against the European Union," The Publications of the MultiScience - XXVIII microCAD International Multidisciplinary Scientific Conference, Miskolc, 1011 April 2014.

[19]M. Romanowska, Planowanie strategiczne wprzedsiębiorstwie, Warszawa: PWE, 2004.

[20] M. Man and M. Nowicka-Skowron, "Costs related to the functions of company logistics," Polish Journal of Management Studies, vol.1, pp. 23-33, 2010.

[21]S. Ostasiewicz, Z. Rusnak, and U. Siedlecka, Statystyka - elementy teorii i zadania, Wrocław: Wydawnictwo Uniwersytetu Ekonomicznego we Wrocławiu, 2011.

[22] W. Krysicki, J. Bartos, W. Dyczka, K. Królikowska, and M. Wasilewski, Rachunek prawdopodobieństwa i statystyka matematyczna w zadaniach, Warszawa: PWN, 2006.

[23] M.F. Triola, Elementary Statistics, London: Pearson, 2012. 